\title{
EVALUATION OF THE EFFICIENCY OF BIRD-BAITED TRAPS FOR SAMPLING POTENTIAL West Nile FeVer mosquito vectors (Diptera: Culicidae) in Senegal
}

\author{
DIALLO D.*, BA Y.*, DIA I.*, SALL A.A.** \& DIALLO M.*
}

\section{Summary:}

The efficiency of bird-baited traps and collection heights for sampling potential West Nile mosquito vectors was studied during the 2006 rainy season (between September 27 and November 26) in Barkedji area situated in the sahelian area of Senegal (West Africa). Each night, two traps were set on the ground-level and two on the canopy-level $(\sim 3 \mathrm{~m})$ each containing either a chicken or a pigeon, the traps being rotated the following nights. A total of 1,030 mosquitoes were collected using 66 traps-nights. Culex species were predominant and represented $92.2 \%$ of the fauna of which $63 \%$ belonged to $C x$. neavei group Theobald whereas $23.8 \%$ were $C x$ poicilipes (Theobald). The species of the $C x$. neavei group were mainly collected by the pigeon-baited trap at canopy while $C x$. poicilipes was captured similarly by pigeons and chickens placed at the canopy and ground. The implication of these results in West Nile vectors surveillance is discussed.

KEY WORDS: West Nile Fever, Cx. neavei group, Cx. poicilipes, traps, chicken, pigeon, level of collection, Senegal.
Résumé : ÉVALUATION DE L'EFFICACITÉ DE PIÈGES À APPÂT-OISEAUX DANS l'ÉChantillonage des moustiques (Diptera : Culicidae) VeCTeURS POTENTIELS du VIRUS West Nile Au SÉNÉGAL

Cette étude décrit l'influence de la hauteur de la mise en place des pièges et de l'espèce d'oiseau utilisée comme appât dans la collecte des moustiques (Diptera: Culicidae) vecteurs potentiels du virus West Nile. Elle a été réalisée durant la saison des pluies 2006 (entre le 27 septembre et le 26 novembre 2006) dans la localité de Barkedii (Sénégall), située dans la zone sahélienne du Ferlo. Deux pièges ont été placés au sol et deux au niveau de la canopée $(\sim 3 \mathrm{~m})$, chacun contenant un poulet ou un pigeon par nuit de capture avec rotation des pièges les nuits suivantes. Au total, 1030 femelles de moustiques ont été collectées avec 66 piègesnuits. Le genre Culex a été le plus abondant car représentant $92,2 \%$ de la faune dont $63 \%$ et $23,8 \%$ constitués respectivement par le groupe Cx. neavei Theobald et Cx. poicilipes (Theobald). Les espèces du groupe Cx. neavei ont été principalement collectées par le piège appâté avec un pigeon au niveau de la canopée tandis que Cx. poicilipes a été capturé de façon comparable par les pièges avec pigeons ou poulets placés au niveau de la canopée et du sol. L'implication de ces résultats dans la surveillance des vecteurs du virus West Nile est discutée.

MOTS CLÉS : fièvre à virus West Nile, Cx. neavei group, Cx. poicilipes, piège, poulet, pigeon, niveau de capture, Sénégal.

species ( $C x$. neavei et $C x$. univittatus) difficult to identify on morphological characters - only adult males were firmly identified in Madagascar (Fontenille \& Jupp, 1989) - they were pooled here. Previous studies conducted in Barkedji area have shown that: i) Cx. poicilipes and species of $C x$. neavei group reach their highest abundances at the end of the rainy season in OctoberNovember, ii) the two species are attracted by chicken, horse and human, and iii) they have been regularly associated with WNV between 1990 and 2003 (Ba et al., 2006; Crora, 2005). Thus, for a better surveillance of WNV amplification, entomological studies should focus on these species. Such kinds of investigations need the accumulation of knowledge of which the search for the most efficient sampling method is important. Thus, the most efficient method for sampling these mosquitoes is still being explored. Information about the most efficient bird bait species and level to collect these vectors in a focal enzootic transmission area of WNV are lacking. Previous studies have shown that some Culex species

* Unité d'entomologie médicale, Institut Pasteur de Dakar, 36, avenue Pasteur, BP 220, Dakar, Sénégal.

** Unité des arbovirus et virus de fièvres hémorragiques, Institut Pasteur de Dakar, 36, avenue Pasteur, BP 220, Dakar, Sénégal. Correspondence: Dr Mawlouth Diallo.

Tel.: +2213383992 28 - Fax: +221338399210

E-mail: diallo@pasteur.sn 
involved in the transmission of WNV feed mainly on the canopy-level (Anderson et al., 2004; Darbro \& Harrington, 2006) or at equal efficiency on the ground and canopy (Drummond et al., 2006).

The purpose of this study was to compare the efficiency of bird-baited traps using pigeons and chickens and collection heights for sampling potential WNV vectors in the Sahelian area of Senegal.

\section{MATERIALS AND METHODS}

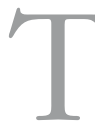

The study was conducted at the edge of the Niakha ponds located about $4 \mathrm{~km}$ north-west of Barkedji

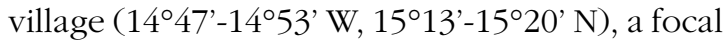
area of enzootic transmission of WNV (Chevalier et $a l$., 2006; 2008) in the Sahelian biogeographic area of Senegal (Fig. 1). This area has a short rainy season which usually lasts from June to September and a long dry season which runs on the rest of the year. Niakha is filled by the first rains and remains flooded two or three months after the last rainfalls. Mosquitoes were collected with a trap (Fig. 2) which is a modified version of the "lard can trap" (Lepore et al., 2004) between September 27 and November 26, 2006, period of highest abundance of WN vectors. This period is further the most appropriate for the virus circulation in that area as witnessed by the regular association of mosquitoes, horses and birds with the virus (Ba et al., 2005; Crora, 2005; Chevalier et al., 2006; 2008).

Each night, excepted the three first nights when only two chicken-trap were set on the canopy, two traps were set on the ground-level $(0 \mathrm{~m})$ and two on the canopy-level $(\sim 3 \mathrm{~m})$ each containing either a chicken (Gallus gallus domesticus) or a pigeon (Columba livia) from dusk to dawn. The traps were rotated the following nights. After each sampling night, collected mosquitoes were recovered by aspiration, killed and identified using the morphological keys of Edwards (1941) and Diagne et al. (1994).

For statistical analysis, the data were transformed using $\log (n+1)$ and the differences in abundance were assessed by comparing the mean number of females per trap per night using an ANOVA mixed model with random effects. The ANOVA was followed by Fisher PLSD tests if a difference were significant at $p=0.05$. The analysis compared sites, days, bird baits species and specific level of collection differences and were done using XLSTAT ${ }^{\circledR} 2009$ software.

\section{RESULTS}

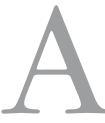
total of 1,030 mosquitoes were collected in the Chicken-Canopy trap (CC), the Chicken-Ground trap (CG), the Pigeon-Canopy trap (PC) and the Pigeon-Ground trap (PG) using 66 traps-nights (Table I). Among these 950 (92.2\%) belong to the Culex genera of which 649 (63\%) were represented by species of the CX. neavei group and $245(23.8 \%)$ by $C x$. poicilipes. The mean number of females collected by the four different traps were statistically comparable for $C x$. poicilipes $(\mathrm{F}=1.8 ; \mathrm{p}=0.16)$ whereas these means were significantly different for the species of the $C x$. neavei group and the whole mosquitoes $(\mathrm{F} \geqslant 6.6 ; \mathrm{p} \leqslant 0.001)$. The number of mosquitoes collected in the PC for the

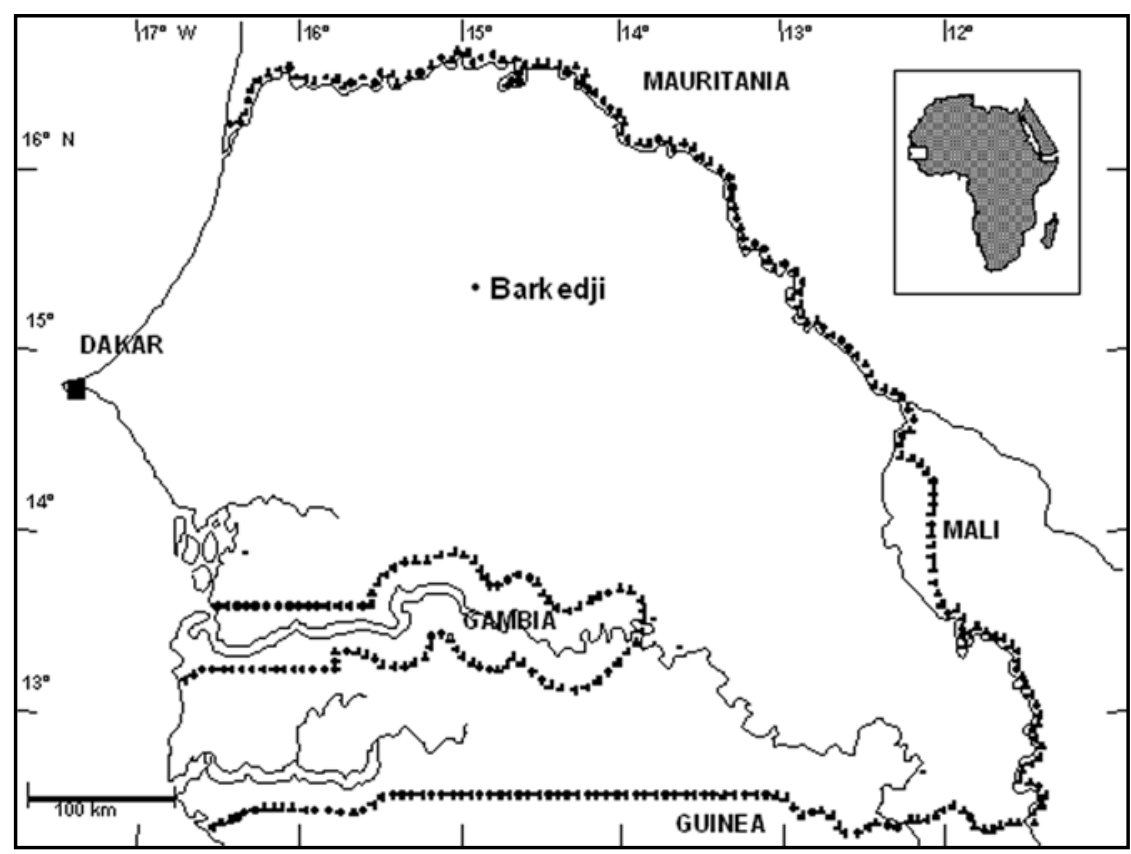

Fig. 1. - Localisation of the study sites. 


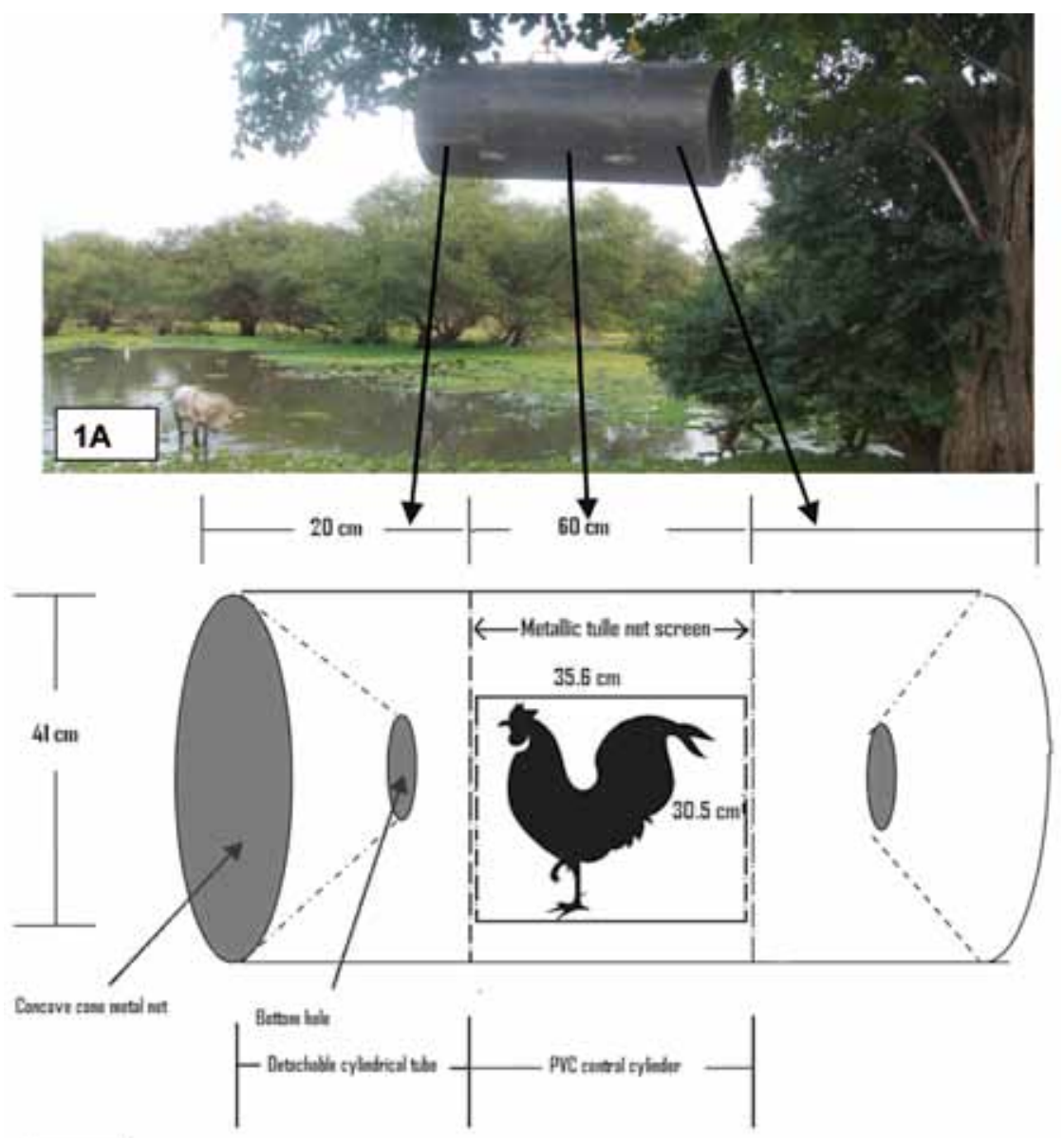

Fig. 2. - Photograph (1A) and diagram (1B) of the bird-baited trap (adapted from Lepore et al., 2004).

species of the Cx. neavei group $(25.5 \pm 4.3)$ and the whole mosquitoes $(35.9 \pm 5.6)$ was higher than those obtained in the others traps (Table II). For these two groups, the CG and PG collected significantly fewer mosquitoes than the others traps.

\section{DISCUSSION}

1 The dominance of Culex species in the mosquito fauna collected is due to the fact that this genus is composed mainly by ornithophilic species (Clements, 1999).

Significant differences can be observed when the levels in which some species are collected according to the geographical and ecological context are compared. Indeed, the species of $C x$. neavei group, were frequently collected at all levels between 0 and $6 \mathrm{~m}$ over open farmland in The Gambia (Gillies \& Wilkes, 1976), at the ground-level in irrigated rice fields (Snow, 1979) and beyond $3 \mathrm{~m}$ height over open ground (Snow, 1975), while at Niakha it was mainly collected at the canopylevel $(\sim 3 \mathrm{~m})$. Similarly to the observations made by
Snow (1975) in The Gambia, our study found that $C x$. poicilipes was common at all levels.

Among the factors explaining the vertical dynamic of the mosquito vectors, the habitat of their host is probably the most important. Indeed, Snow (1975) investigated the vertical distribution of mosquitoes in The Gambia and observed that zoophagic mosquitoes were mainly collected near the ground, ornithophilic mosquitoes in the canopy and mosquitoes feeding on mammals and birds at all levels.

Contrary to a study conducted in California, showing an attraction and a feeding preference of Culex mosquitoes on chickens rather than pigeons (Reisen et al., 1992), our results indicated the preference of mosquitoes for pigeons instead of chickens at least for species of the $C x$. neavei group. This means that the pigeonbaited trap could be better than the chicken-baited trap in WNV vector surveillance in Senegal. Moreover, the use of pigeons could be encouraged by the fact that they were frequently found infected by WNV in New York (Komar et al., 2001) and their size make them easier to manipulate compared to chickens (Reisen et al., 1992). Our study shows finally that, in the case of 


\begin{tabular}{|c|c|c|c|c|}
\hline \multirow[b]{2}{*}{ Species } & \multicolumn{3}{|c|}{ Number of mosquitoes collected } & \multirow[t]{2}{*}{$\%$} \\
\hline & Ground-level & Canopy-level & Total & \\
\hline Ae. aegypti & & 1 & 1 & 0.1 \\
\hline Ae. ochraceus & 1 & & 1 & 0.1 \\
\hline Ae. vexans & 1 & & 1 & 0.1 \\
\hline An. ziemanni & 2 & & 2 & 0.2 \\
\hline Ma. africana & 72 & 1 & 73 & 7.1 \\
\hline Ma. uniformis & 2 & & 2 & 0.2 \\
\hline Total mosquitoes except Culex & 78 & 2 & 80 & 7.8 \\
\hline CX. antennatus & & 2 & 2 & 0.2 \\
\hline CX. bitaeniorbynchus & & 1 & 1 & 0.1 \\
\hline CX. ethiopicus & 3 & 34 & 37 & 3.6 \\
\hline Cx. neavei group* & 33 & 616 & 649 & 63.0 \\
\hline Cx. perfuscus & 1 & 14 & 15 & 1.5 \\
\hline CX.poicilipes & 139 & 106 & 245 & 23.8 \\
\hline Cx. tritaeniorbychus & & 1 & 1 & 0.1 \\
\hline Total Culex & 176 & 774 & 950 & 92.2 \\
\hline Total mosquitoes & 254 & 776 & 1030 & 100 \\
\hline
\end{tabular}

* Cx. neavei group includes Cx. neavei and/or Cx. univittatus.

Table I. - Mosquitoes collected by bird-baited traps on the canopy and the ground levels between September 27 and November 26, 2006, at Barkedji, Senegal.

\begin{tabular}{|c|c|c|c|}
\hline \multirow{2}{*}{ Trap } & \multicolumn{3}{|c|}{ Abundance (Females/ Trap/ Night \pm Standard Error) } \\
\hline & Cx. poicilipes & Cx. neavei group & Mosquitoes \\
\hline Pigeon-ground & $2.9 \pm 1.2^{\mathrm{a}}$ & $0.7 \pm 0.2^{\mathrm{c}}$ & $9.4 \pm 2.0^{\mathrm{b}}$ \\
\hline Pigeon-canopy & $2.5 \pm 1.1^{\mathrm{a}}$ & $25.5 \pm 4.3^{\mathrm{a}}$ & $35.9 \pm 5.6^{\mathrm{a}}$ \\
\hline Chicken-ground & $5.8 \pm 1.6^{\mathrm{a}}$ & $1.4 \pm 0.4^{c}$ & $6.6 \pm 2.0^{c}$ \\
\hline Chicken -canopy & $3.4 \pm 1.1^{\mathrm{a}}$ & $8.7 \pm 2.0^{b}$ & $11.8 \pm 2.0^{b}$ \\
\hline
\end{tabular}

a b c For Cxpoicilipes, $C x$. neavei group and mosquitoes, the means with the same letter $(\mathrm{a}, \mathrm{b}$ or $\mathrm{c}$ ) are statistically comparable. The mean with the letter (a) is significantly higher followed by (b) and (c).

Table II. - Means number of mosquitoes collected by pigeon and chicken bait on the ground and canopy levels between September 27 and November 26, 2006, at Barkedji, Senegal. Means with different letters are significantly different at $\mathrm{p}=0.05$.

Barkedji, the bird-baited trap should be elevated in the canopy for better efficiency. Anderson et al. (2004) in the context of the New World showed that a significantly higher number of WNV strains were isolated in traps placed in the canopy-level compared to ground-level traps. Thus, the canopy is the ideal level where should be placed the bird-baited traps to sample ornithophilic mosquitoes for virus isolation attempts.

\section{ACKNOWLEDGEMENTS}

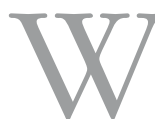

e would like to thank Sadio Sow and Bidiel Fall for their technical assistance. This work was partially funded by EU grant GOCE-2003010284 EDEN (the paper is catalogued by the EDEN
Steering Committee as EDEN0209). The contents of this publication are the responsibility of the authors only and do not necessarily reflect the views of the European Commission.

\section{REFERENCES}

Anderson J.F., Andreadis T.G., Main A.J. \& Kline D.L. Prevalence of West Nile virus in tree canopy-inhabiting Culex pipiens and associated mosquitoes. American Journal of Tropical Medicine and Hygiene, 2004, 71, 112-119.

Ba Y., Diallo D., Kebe C.M.F., Dia I. \& Diallo M. Aspects of bioecology of two Rift Valley Fever Virus vectors in Senegal (West Africa): Aedes vexans and Culex poicilipes (Diptera: Culicidae). Journal of Medical Entomology, 2005, 42, 739-750. 
Ba Y., Diallo D., Dia I. \& Diallo M. Comportement trophique des vecteurs du virus de la fièvre de la vallée du Rift au Sénégal: implications dans l'épidémiologie de la maladie. Bulletin de la Société de Pathologie Exotique, 2006, 99, 283-289.

Campbell G., Marfin A., Lanciotti R. \& Gubler D. West Nile virus. Lancet Infectious Diseases, 2002, 2, 519-529.

Chevalier V., Lancelot R., Diaite A., Mondet B., Sall B. \& De Lamballerie X. Serological assessment of West Nile fever virus activity in the pastoral system of Ferlo Senegal. Annals of the New York Academy of Sciences, 2006, 1081, 216-225.

Chevalier V., Lancelot R., Diaite A., Mondet B. \& De LambalLERIE X. Use of sentinel chickens to study the transmission dynamics of West Nile virus in a sahelian ecosystem. Epidemiology and infection, 2008, 136, 525-528.

Clements A.N. The biology of mosquitoes, vol. 2. Sensory reception and behavior. CABI, New York, 1999.

CRORA, Centre collaborateur OMS de référence et de recherche sur les arbovirus africains. Base de données sur les caractéristiques d'arbovirus africains isolés par l'Institut Pasteur de Dakar. www.pasteur.fr/recherche/banques/CRORA/, 2005 (accès le 2 juillet 2007)

DARBRO J.M. \& HARRINGTON L.C. Bird-baited traps for surveillance of West Nile mosquito vectors: effect of bird species, trap height, and mosquito escape rates. Journal of Medical Entomology, 2006, 43, 83-92.

Diagne N., Fontenille D., Konate L., Faye O., Traore-Lamizana M., Legros F., Molez J.F. \& Trape J.F. Les anophèles du Sénégal. Liste commentée et illustrée. Bulletin de la Société de Pathologie Exotique, 1994, 87, 267-277.

Drummond C.L., Drobnack J., Backenson R.B., Ebel G.D. \& KRAMER L.D. Impact of trap elevation on estimates of abundance, parity rates, and body size of Culex pipiens and Culex restuans (Diptera: Culicidae). Journal of Medical Entomology, 2006, 43, 177-184.

EDWARDS F.W. Mosquitoes of the Ethiopian region. III Culicine Adults and Pupae. British Museum (Natural History), London, 1941.

FonTENILLE D. \& Jupp P.G. Présence du moustique Culex (Culex) neavei à Madagascar. Conséquence dans la transmission des arbovirus. Archive Institut Pasteur Madagascar, 1989, 56, 287-295.

Gillies M.T. \& Wilkes T.J. The vertical distribution of some West African mosquitoes (Diptera: Culicidae) over open farmland in a freshwater area of the Gambia. Bulletin of Entomological Research, 1976, 66, 5-15.

Komar N., Panella N., Burns J., Dusza J., Mascarenhas T. \& TALBOT T. Serologic evidence for West Nile virus infection in birds in the New York City vicinity during an outbreak in 1999. Emerging Infectious Diseases, 2001, 7, 621-625.

LePore T.J., Pollack R.J., Spielman A. \& Reiter P. A readily constructed lard can trap for sampling host-seeking mosquitoes. Journal of the American Mosquito Control Association, 2004, 20, 321-322.

Murgue B., Zeller H. \& Deubel V. The ecology and epidemiology of West Nile virus in Africa, Europe and Asia, in: Mackenzie J.S., Barrett A.D.T. \& Deubel V. (eds), New York:
Springer. Current Topics in Microbiology and Immunology, 2002, 267, 195-221.

ReIsEN W.K., Hardy J.L. \& Presser S.B. Evaluation of domestic pigeons as sentinels for detecting arbovirus activity in southern California. American Journal of Tropical Medicine and Hygiene, 1992, 46, 69-79.

SNOW W.F. The vertical distribution of flying mosquitoes (----Diptera: Culicidae) in West African savanna. Bulletin of Entomological Research, 1975, 65, 269-277.

SNOw W.F. The vertical distribution of flying mosquitoes (Diptera: Culicidae) near an area of irrigated rice-fields in the Gambia. Bulletin of Entomological Research, 1979, 69, 561-571.

Taylor R.M., Work T.M., Hurlbut H.S. \& Rizk F. A study of the ecology of West Nile virus in Egypt. American Journal of Tropical Medicine and Hygiene, 1956, 5, 579-620.

Traore-Lamizana M., Zeller H.G., Mondo M., Hervy J.P., Adam F. \& DigoutTE J.P. Isolations of West Nile and Bagaza viruses from mosquitoes (Diptera: Culicidae) in central Senegal (Ferlo). Journal of Medical Entomology, 1994, 31, 934-938.

Traore-lamizana M., Fontenille D., Diallo M., Ba Y., Zeller H.G., Mondo M., Adam F., Thonnon J. \& Maiga A. Arbovirus surveillance from 1990 to 1995 in the Barkedji area (Ferlo) of Senegal, a possible natural focus of Rift Valley fever virus. Journal of Medical Entomology, 2001, 38, 480-492.

Reçu le 14 septembre 2009 Accepté le 19 mars 2010 